\title{
Impact of Paper Mill Effluent on Seed Germination and Seedling Growth of Coriander (Coriandrum sativum) Varieties
}

\author{
Kamlesh \\ Department of Energy \& Environmental Sciences, Chaudhary Devi Lal University, Sirsa, India
}

\begin{abstract}
Diverse nature of agro-based industrial effluents from various industries are disposed off in to soil and water bodies, which has been causing major pollution problem. To economize the irrigation water industrial effluents are now a days commonly used for irrigation. The present study has been carried out to assess the impact of paper mill effluent on seed germination and seedling growth of Coriander (Coriandrum sativum) varieties KS and Mehak. The pot culture experiment was conducted with the different concentrations like viz., 10\%, 20\%, 30\%, 40\%, 50\%, 60\%, $70 \%, 80 \%, 90 \%$ and $100 \%$ along with control (Tap water). Physico-chemical parameters included colour, $\mathrm{pH}$, temperature, turbidity, electrical conductivity (EC), total solids (TS), total dissolved solids (TDS), suspended solids (SS), chemical oxygen demand (COD), biochemical oxygen demand (BOD), total hardness (TH), total alkalinity (TA) and chloride $\left(\mathrm{Cl}^{-}\right)$. The growth parameters such as germination percentage, seedling vigour, plant length, fresh and dry weight were measured at $14^{\text {th }}$ DAS (days after sowing). The results indicate that at lower concentration there is a significant increase in the percentage of seed germination and other growth parameters but decreased with increase in effluent concentration.
\end{abstract}

Keywords-Coriander, germination percentage, paper mill, Mehak, seedling vigour.

\section{INTRODUCTION}

Pulp and paper industry is very important industry for the overall development of a country and it is partially or completely dependent on ligno cellulose crop residues. In northern India most of the pulp and paper mills manufacture paper using agricultural residues mainly from crops straws. For manufacturing of a huge amount of water is required and thus it release large volume of waste water. It is estimated that 273-450 $\mathrm{M}^{3}$ of water is required per ton of paper produced (Subrahmanyam and Hannmanulu, 1976) that consequently, generate $300 \mathrm{M}^{3}$ of waste water
(Khanna et al., 1990). The effluents generated from pulp and paper mill is dark brown in colour and having high BOD, COD, TS and organic carbon (Kirk et al., 1983; Singh et al., 1994). From literature it was found that the first alkaline extraction state is the major source of pollutants (approximately 95\% of total pollution load) from pulp and paper (Ragan, 1987; Singh et al., 1994). At present, there are 666 pulp and paper mills in India, of which 632 units are agro-residue and recycled fiber based units with manufacturing capacity of 7.6 million tons (CPPRI, 2005). The Indian pulp and paper industry is highly water intensive, consuming 100-250 m3 freshwater/ton paper (Singh, 2004) and also generate the corresponding wastewater 75-225 m3 wastewater/ton paper (Thompson, 2001; Ansari, 2004; Tewari et al., 2009). There are more than 20 types of industries including paper industry falls under red category because of their potentiality in polluting the environment (CPCB, 2016).

Treated industrial effluents can be used for irrigation purpose. When the effluent is used without any treatment, toxic substances present in the effluent reduces crop growth and gives severe adverse effect on soil properties (Somashekar et al., 1984; Juwarker et al., 1987, Garg and Kaushik, 2006). Studies on the effect of paper mill effluent on various crops have been carried out by various investigators. Chaudhary et al. (1987) studied the effect of paper mill effluent on germination, seedling growth and chlorophyll content in Zea mays L. It was observed that highest overall growth was found upto $25 \%$ concentration of effluent but chlorophyll content was higher at $75 \%$. Dutta and Boissya (1996) studied the effect of paper industry effluent on germination in Oryza sativa L and found that in effluent affected areas, germination percentage and yield were comparatively less. Singh et al. (2002) studied the effect of effluent in Triticum aestivum L. and noticed that diluted effluent showed increase in chlorophyll content, plant height, shoot and root biomass, grain yield 
etc. whereas concentrated effluent showed a decrease in parameters.

Coriandrum Sativum family Umbelliferae is highly reputed ayurvedic medicinal tree commonly known as the Dhaniya. Dhaniya consist of dried ripe fruit of Coriandrum Sativum Linn Umbeliferae (Evans and Treas, 2002) a slender, glabrous, branched, cultivated all over India, giving characteristic aroma when rubbed. All parts of the plant are edible, but the fresh leaves and the dried seeds are the most common parts used in cooking. The different parts of this plant contain monoterpenes, $\alpha$-pinene, limpnene, $\gamma$ terpinene, p-cymene, borneol, citronellol, camphor, geraniol, coriandrin, dihydrocoriandrin, coriandrons A-E, flavonoids and essential oils. Various parts of this plant such as seed, leaves, flower and fruit, possess diuretic, antioxidant activity, anti-diabetic anti-convulsant activity, sedative hypnotic activity, anti-microbial activity, anti mutagenic, anthelmintic activity (Pathak et al., 2011). Coriander has been used for a number of medical problems such as dyspeptic complaints, loss of appetite, convulsion and insomnia (Benjumea et al., 2005; Maghrani et al., 2005; Heidar et al., 1992; Zargari et al., 1991; Duke et al., 2002).

\section{MATERIALS AND METHODS}

\section{Experimental design}

The pot culture experiment was conducted in the laboratory of Department of Energy and Environmental Sciences, Chaudhary Devi Lal University, Sirsa. The effect of paper mill effluent on the initial growth parameters such as germination percentage, seedling vigour, plant length, fresh and dry weight were studied using disposable pots $(8.5 \mathrm{~cm}$ height and $7 \mathrm{~cm}$ width), filled with air dried soil taken into separate pots. The soil used in the experiment was sandy loam in nature. The methodology of Aery (2010) was adopted for surface sterilization of the test seeds of both varieties with $0.1 \%$ mercuric chloride $\left(\mathrm{HgCl}_{2}\right)$ for 30 seconds and vigorously rinsed with DDW three times to remove traces of $\mathrm{HgCl}_{2} .10$ seeds were sowed in each pot of each variety in different dilutions i.e control, $10 \%, 20 \%$, $30 \%, 40 \%, 50 \%, 60 \%, 70 \%, 80 \%, 90 \%$ and $100 \%$ along with control to study the response of both the varieties. All pots were watered to field capacity daily.

\section{Effluent collection and analysis}

The sample of paper mill effluent was collected from outlet in precleaned, sterilized plastic containers from Shree Jagdambe paper mills ltd., Sirsa, Haryana, India and was stored at $4^{\circ} \mathrm{C}$ till further investigation as described by APHA (2010). Physico-chemical parameters, such as colour, $\mathrm{pH}$, temperature, electrical conductivity (EC), total solids (TS), total dissolved solids (TDS), total suspended solids (TSS), chemical oxygen demand (COD), biochemical oxygen demand (BOD), total hardness (TH), total alkalinity (TA) and chloride $\left(\mathrm{Cl}^{-}\right)$were measured using standard methods (APHA, 2010). Different concentrations i.e 10\%, $20 \%, 30 \%, 40 \%, 50 \%, 60 \%, 70 \%, 80 \%, 90 \%$ and $100 \%$ were prepared by adding desired volume of tap water (municipal supply) collected from sector 13, Bhiwani and used for the proposed pot trials.

\section{Collection of seeds}

Commercially available seeds of Coriander (Coriandrum sativum) varieties $\mathrm{KS}$ and Mehak were procured from the certified local seed supplier, Bhiwani, used in the study. Seeds with uniform size, colour and weight were chosen for the experimental purpose.

\section{Initial Growth analysis}

The test plant samples of both varieties were harvested 14th days after sowing. Three plants from each pot were analysed for various initial growth parameters such as germination percentage, seedling vigour, plant fresh weight, dry weight and plant length by following the methodology of Aery (2010).

\section{Germination percentage}

The number of seeds germinated in each treatment was observed on $14^{\text {th }}$ DAS (day after sowing). The total germination percentage was calculated by using the following formula:

Germination percentage $=$

Total number of seeds germinated $\times 100$

Total number of seeds sown

\section{Seedling vigour index}

Vigour index of the seedling were calculated by using the formula proposed by Aery (2010).

Seedling vigour index $=$ Germination percentage $\times$ seedling length

\section{Statistical analysis}

The statistical analysis was carried out by using SPSS software (Version 20). Data were analyzed for mean, standard error and one way analysis of variance. ANOVA was done at 0.05 levels to find out the significant difference between different concentrations of effluent and different parameters of growth and development of the crops.

\section{RESULTS AND DISCUSSION}

In the present study paper mill waste water which was used for irrigation of Coriander (Coriandrum sativum) varieties KS and Mehak was analysed to know the physico-chemical 
parameters of waste water and its effect on initial growth parameters such as germination percentage, seedling vigour, plant length, fresh and dry weight. The results of physicochemical characteristics of paper mill effluent are presented in Table-1.

The characterization of the effluent revealed that it is dark brown in colour having temperature of $20.2^{\circ} \mathrm{C}$ and turbidity of 12 NTU. The $\mathrm{pH}$ of the effluent was found alkaline in nature having $\mathrm{pH}$ of 8.2 . The value of total solids, total dissolved solids and suspended solids were $1700 \mathrm{mg} / \mathrm{l}, 1440$ $\mathrm{mg} / \mathrm{l}$ and $260 \mathrm{mg} / \mathrm{l}$ respectively. The electrical conductivity (EC) value was $2.25 \mu \mathrm{S}$. The effluent had higher BOD, 282 $\mathrm{Mg} / \mathrm{l}$ and COD, $960 \mathrm{mg} / \mathrm{l}$. The higher concentration of BOD and COD indicated the higher concentration of organic and inorganic substances in the effluent. The recommended BIS values for BOD and COD are $100 \mathrm{mg} / \mathrm{l}$ and $250 \mathrm{mg} / \mathrm{l}$ respectively. Further the values of total hardness $(\mathrm{TH})$, total alkalinity (TA) and chloride were $770 \mathrm{mg} / \mathrm{l}, 440 \mathrm{mg} / \mathrm{l}$ and $510 \mathrm{mg} / \mathrm{l}$ respectively. The presence of high amount of COD, BOD, suspended solids, total hardness were also recorded by Baruah et al., 1996; Medhi et al., 2008.

The observation made on the effects of paper mill effluent on growth parameters of Coriander (Coriandrum sativum) varieties KS and Mehak are presented in Table $2 \& 3$. The results clearly indicate the growth parameters like germination percentage, seedling vigour, plant length, fresh and dry weight of both varieties varied with respect to different concentrations of paper mill effluent. The degree of inhibitory effect of paper mill effluent on the growth of test varieties KS and Mehak increased with the increase in the concentration of effluent when compared to the control.

Table.1: The physico-chemical analysis of paper mill effluent

\begin{tabular}{|c|c|c|c|c|c|}
\hline S.No. & Parameters & Effluent & Control & $\begin{array}{l}\text { BIS for drinking } \\
\text { water }\end{array}$ & $\begin{array}{c}\text { BIS for irrigation } \\
\text { water }\end{array}$ \\
\hline 1 & Colour & Dark brown & Colourless & Colourless & \\
\hline 2 & $\mathrm{pH}$ & 8.2 & 7.3 & $6.5-8.5$ & $5.5-9$ \\
\hline 3 & Temperature $\left({ }^{\circ} \mathrm{C}\right)$ & 20.2 & 18.1 & - & - \\
\hline 4 & Turbidity(NTU) & 12 & 1.5 & 5 & 10 \\
\hline 5 & $\mathrm{TS}(\mathrm{mg} / \mathrm{l})$ & 1700 & & 600 & 1900 \\
\hline 6 & TDS (mg/l) & 1440 & 84 & 500 & 2100 \\
\hline 7 & $\mathrm{SS}(\mathrm{mg} / \mathrm{l})$ & 260 & & 100 & 200 \\
\hline 8 & $\mathrm{EC}(\mu \mathrm{S})$ & 2.25 & 0.13 & - & - \\
\hline 9 & BOD (mg/l) & 282 & 1.8 & 4 & 100 \\
\hline 10 & $\mathrm{COD}(\mathrm{mg} / \mathrm{l})$ & 960 & & & 250 \\
\hline 11 & $\mathrm{TH}(\mathrm{mg} / \mathrm{l})$ & 770 & 202 & 300 & 600 \\
\hline 12 & TA $(\mathrm{mg} / \mathrm{l})$ & 440 & 72 & 200 & 600 \\
\hline 13 & Chloride (mg/l) & 510 & 56 & 250 & 500 \\
\hline
\end{tabular}

The result shows that $90 \%$ germination was recorded for KS variety in pot treated with $40 \%$ concentration of effluent while $20 \%$ germination was recorded at $100 \%$ concentration. From 50\% onwards the germination percentage was found to be gradually declined in $\mathrm{KS}$ variety. $50 \%$ germination was recorded in control. Mehak variety showed 83.3 germination percentage in pot treated with $60 \%$ concentration of effluent while 16.7 germination percentage was recorded at $100 \%$ concentration. 33.3 percent germination was recorded in pot treated with tap water. From $60 \%$ onwards the germination percentage was found to be gradually declined in Mehak variety. The KS variety resulted better in terms of early seed germination than Mehak variety showing the inter-varietal difference.
The observation was conformity with Medhi et al. (2008). In present study ANOVA analysis on data showed that effluent concentration $40 \%$ significantly $(\mathrm{P}<0.05)$ affected germination as compared to control in $\mathrm{KS}$ variety while in Mehak variety $50 \%, 60 \%$ and $70 \%$ significantly $(\mathrm{P}<0.05)$ affected germination as compared to control.

The result shows that $25 \mathrm{~cm}$ plant length was recorded for KS variety in pot treated with $50 \%$ concentration while at $100 \%$ concentration $13.23 \mathrm{~cm}$ length was recorded. 16.23 $\mathrm{cm}$ plant length was recorded in control. From 50\% onwards the length was found to be gradually declined in KS variety. Mehak variety showed $23.5 \mathrm{~cm}$ plant length in $30 \%$ concentration of effluent while $12.43 \mathrm{~cm}$ and $13.8 \mathrm{~cm}$ plant length was recorded in control and $100 \%$ 
concentration respectively. Plant length was found to be gradually declined from $30 \%$ concentration onwards. In present study ANOVA analysis on data showed that effluent concentration 20\%, 30\%, 40\%, 50\%, 60\%, 70\% and $100 \%$ significantly $(\mathrm{P}<0.05)$ affected plant length as compared to control in $\mathrm{KS}$ variety while in Mehak variety $20 \%$ to $90 \%$ concentration significantly $(\mathrm{P}<0.05)$ affected plant length as compared to control.

The value of seedling vigour recorded in pot treated with $40 \%$ concentration was 2353.3 while at $100 \%$ concentration 261 vigour was recorded. Value of seedling vigour for control was found to be 812 for KS variety. Mehak variety showed 1731.3 seedling vigour at $60 \%$ concentration of paper mill effluent while value of seedling vigour for control and $100 \%$ concentration was observed to be 392 and 227.7 respectively. Vigour was found to be gradually declined from $60 \%$ concentration onwards in Mehak variety. ANOVA analysis on data showed that effluent concentration 20\%, 30\%, 40\% and $50 \%$ significantly $(\mathrm{P}<0.05)$ affected seedling vigour as compared to control in $\mathrm{KS}$ variety while in Mehak variety $30 \%$ to $70 \%$ concentration significantly $(\mathrm{P}<0.05)$ affected vigour as compared to control.

Table.2: Growth parameters of Coriander variety $(K S)$ under different concentration of paper mill effluent $(n=3, M e a n \pm S E)$

\begin{tabular}{|c|c|c|c|c|c|}
\hline Treatment & $\begin{array}{c}\text { Germination } \\
\text { \% }\end{array}$ & $\begin{array}{c}\text { Plant Length } \\
(\mathbf{c m})\end{array}$ & $\begin{array}{c}\text { Seedling } \\
\text { vigour }\end{array}$ & $\begin{array}{c}\text { Fresh weight } \\
(\mathbf{g m})\end{array}$ & $\begin{array}{c}\text { Dry weight } \\
(\mathbf{g m})\end{array}$ \\
\hline Control & $50.0 \pm 5.77$ & $16.23 \pm 0.12$ & $812 \pm 96.03$ & $0.028 \pm 0.0$ & $0.002 \pm .000$ \\
\hline $\mathbf{1 0 \%}$ & $73.3 \pm 6.67$ & $18.43 \pm 0.67$ & $1360 \pm 165.31$ & $0.025 \pm 0.001$ & $0.003 \pm .001$ \\
\hline $\mathbf{2 0 \%}$ & $80.0 \pm 5.77$ & $21.17 \pm 0.72 \mathrm{a}$ & $1689 \pm 102.5 \mathrm{a}$ & $0.025 \pm 0.001$ & $0.004 \pm .001$ \\
\hline $\mathbf{3 0 \%}$ & $83.3 \pm 3.33$ & $22.90 \pm 0.38 \mathrm{a}$ & $1908.7 \pm 86.07 \mathrm{a}$ & $0.028 \pm .001$ & $0.003 \pm .000$ \\
\hline $\mathbf{4 0 \%}$ & $90.0 \pm 5.77 \mathrm{a}$ & $24.57 \pm 0.78 \mathrm{a}$ & $2353.3 \pm 124.89 \mathrm{a}$ & $0.027 \pm .000$ & $0.003 \pm .000$ \\
\hline $\mathbf{5 0 \%}$ & $73.3 \pm 6.67$ & $25.00 \pm 0.12 \mathrm{a}$ & $1834.7 \pm 173.39 \mathrm{a}$ & $0.023 \pm .002$ & $0.003 \pm .000$ \\
\hline $\mathbf{6 0 \%}$ & $70.0 \pm 5.77$ & $20.83 \pm 0.30 \mathrm{a}$ & $1456 \pm 108.3$ & $0.024 \pm .001$ & $0.004 \pm .001$ \\
\hline $\mathbf{7 0 \%}$ & $66.7 \pm 8.82$ & $18.80 \pm 0.31 \mathrm{a}$ & $1258 \pm 181.27$ & $0.026 \pm .003$ & $0.002 \pm .000$ \\
\hline $\mathbf{8 0 \%}$ & $50.0 \pm 5.77$ & $18.00 \pm 0.12$ & $899.3 \pm 101.72$ & $0.022 \pm .001$ & $0.002 \pm .000$ \\
\hline $\mathbf{9 0 \%}$ & $46.7 \pm 8.82$ & $17.20 \pm 0.52$ & $795.7 \pm 142.36$ & $0.020 \pm .000 \mathrm{a}$ & $0.002 \pm .000$ \\
\hline $\mathbf{1 0 0 \%}$ & $20.0 \pm 5.77$ & $13.23 \pm 0.69 \mathrm{a}$ & $261 \pm 74.36$ & $0.019 \pm .001 \mathrm{a}$ & $0.002 \pm .000$ \\
\hline F-value & 10.024 & 53.301 & 22.320 & 4.522 & $1.809^{*}$ \\
\hline
\end{tabular}

* Not significant at ( $P<0.05), a$ = significantly different to control

For Mehak variety maximum value for fresh weight 0.024 gm was found in pot irrigated with $50 \%$ and $60 \%$ concentration of effluent while for dry weight $0.002 \mathrm{gm}$ was found in $40 \%$ to $60 \%$ concentrations. The value of fresh weight and dry weight for control was found to be $0.023 \mathrm{gm}$ and $0.001 \mathrm{gm}$ respectively. ANOVA analysis on data showed that effluent concentration $90 \%$ and $100 \%$ significantly $(\mathrm{P}<0.05)$ affected fresh weight as compared to control in KS variety. Fresh and dry weight did not differ significantly $(\mathrm{P}<0.05)$ for Mehak variety.

Similar observations were also studied by many workers. Medhi et al., (2008) studied effect of pulp and paper mill effluent on seed germination and seedling growth of mustard, pea and rice and found that lower concentrations of effluent had a growth promoting effect than control. Reddy and Borse (2001) studied the effect of the effluent on germination and seedling growth in Trigonella foenum graceum L. and found that there was increase in germination and seedling growth upto $25 \%$ concentration and above it, there was decline in parameters. Kamlesh and Kidwai, (2016) studied effect of sugar mill effluent on Fenugreek (Trigonella foenum-graecum) varieties (Kasuri) and (Pusa Bold) and found that higher effluent concentrations affect initial growth parameters while lower dilutions favoured initial plant growth of both the plant varieties. 
Table.3: Growth parameters of Coriander variety (Mehak) under different concentration of paper mill effluent (Mean \pm SE)

\begin{tabular}{|c|c|c|c|c|c|}
\hline Treatment & $\begin{array}{c}\text { Germination } \\
\text { \% }\end{array}$ & $\begin{array}{c}\text { Plant Length } \\
(\mathbf{c m})\end{array}$ & $\begin{array}{c}\text { Seedling } \\
\text { vigour }\end{array}$ & $\begin{array}{c}\text { Fresh weight } \\
\text { (gm) }\end{array}$ & $\begin{array}{c}\text { Dry weight } \\
\text { (gm) }\end{array}$ \\
\hline Control & $33.3 \pm 8.82$ & $12.43 \pm 1.27$ & $392 \pm 61.78$ & $0.023 \pm 0.003$ & $0.001 \pm 0.0$ \\
\hline $\mathbf{1 0 \%}$ & $40 \pm 5.77$ & $15.2 \pm 0.77$ & $614 \pm 117.36$ & $0.024 \pm 0.0$ & $0.001 \pm 0.0$ \\
\hline $\mathbf{2 0 \%}$ & $43.3 \pm 3.33$ & $19.3 \pm 0.72 \mathrm{a}$ & $832 \pm 36.3$ & $0.022 \pm 0.003$ & $0.001 \pm 0.0$ \\
\hline $\mathbf{3 0 \%}$ & $46.7 \pm 3.33$ & $23.5 \pm 0.71 \mathrm{a}$ & $1096 \pm 90.86 \mathrm{a}$ & $0.019 \pm 0.004$ & $0.001 \pm 0.001$ \\
\hline $\mathbf{4 0 \%}$ & $60 \pm 5.77$ & $23.2 \pm 0.46 \mathrm{a}$ & $1394.7 \pm 147.25 \mathrm{a}$ & $0.020 \pm 0.001$ & $0.002 \pm 0.0$ \\
\hline $\mathbf{5 0 \%}$ & $73.3 \pm 3.33 \mathrm{a}$ & $22.4 \pm 0.55 \mathrm{a}$ & $1648.7 \pm 115.95 \mathrm{a}$ & $0.024 \pm 0.003$ & $0.002 \pm 0.0$ \\
\hline $\mathbf{6 0 \%}$ & $83.3 \pm 6.67 \mathrm{a}$ & $20.7 \pm 0.29 \mathrm{a}$ & $1731.3 \pm 159.01 \mathrm{a}$ & $0.024 \pm 0.001$ & $0.002 \pm 0.001$ \\
\hline $\mathbf{7 0 \%}$ & $70 \pm 5.77 \mathrm{a}$ & $19.9 \pm 0.18 \mathrm{a}$ & $1396.7 \pm 122.7 \mathrm{a}$ & $0.017 \pm 0.0$ & $0.001 \pm 0.0$ \\
\hline $\mathbf{8 0 \%}$ & $46.7 \pm 8.82$ & $19.3 \pm 0.18 \mathrm{a}$ & $900.7 \pm 174.95$ & $0.019 \pm 0.0$ & $0.001 \pm 0.0$ \\
\hline $\mathbf{9 0 \%}$ & $36.7 \pm 8.82$ & $17.2 \pm 0.64 \mathrm{a}$ & $632.7 \pm 162.28$ & $0.020 \pm 0.001$ & $0.001 \pm 0.0$ \\
\hline $\mathbf{1 0 0 \%}$ & $16.7 \pm 3.33$ & $13.8 \pm 0.38$ & $227.7 \pm 41.43$ & $0.017 \pm 0.001$ & $0.001 \pm 0.0$ \\
\hline F-value & 10.132 & 34.902 & 17.490 & $2.134 *$ & $0.776^{*}$ \\
\hline
\end{tabular}

* Not significant at ( $P<0.05), a=$ significantly different to control

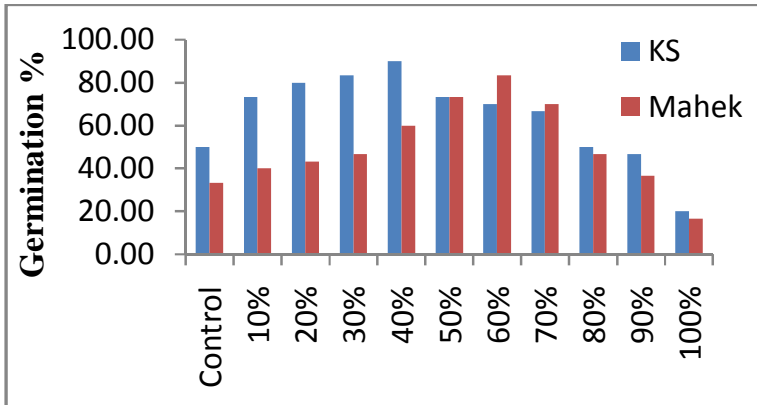

Fig.1: Impact of paper mill effluent on germination (\%)

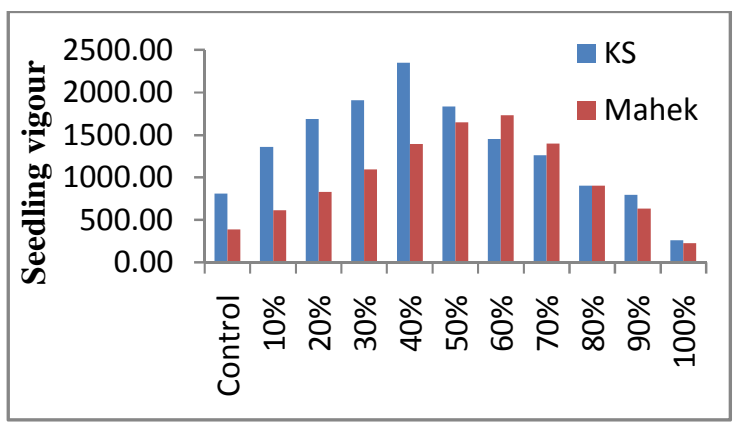

Fig.2: Impact of paper mill effluent on seeding vigour

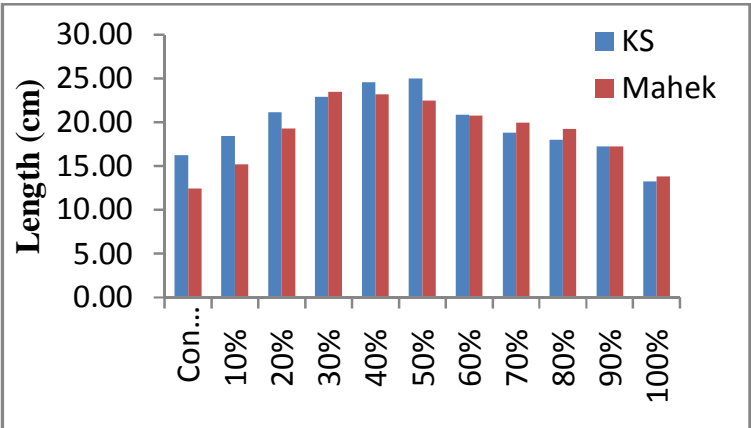

Fig.3: Impact of paper mill effluent on plant length

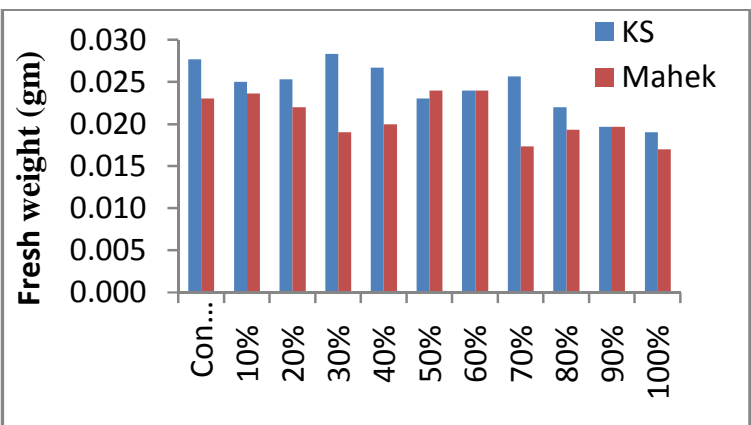

Fig.4: Impact of paper mill effluent on fresh weight 


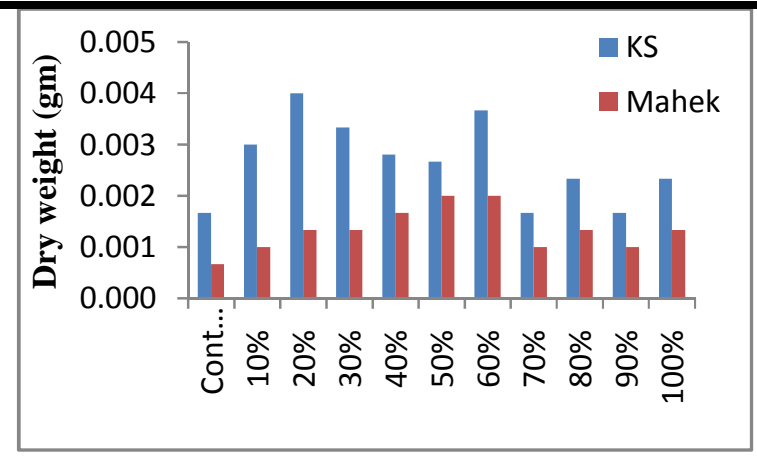

Fig.5: Impact of paper mill effluent on dry weight

\section{CONCLUSION}

In the present study paper mill effluent was studied to know its effect on initial growth parameters such as germination percentage, seedling vigour, plant length, fresh and dry weight of Coriander (Coriandrum sativum) varieties KS and Mehak. From the conducted work, it is concluded that paper mill effluent had adverse effect on growth parameters at higher concentration, but lower concentrations favoured initial plant growth of both the plant varieties. However, long term research work should be conducted to explore the effect of paper mill effluent on above suggested aspects before its use for irrigation.

\section{REFERENCES}

[1] Aery, N.C. (2010). Manual of Environmental Analysis. Anne Books pvt.Ltd.

[2] American Public Health Association (2010).Standard methods for examination of water and waste water, APHA, Washington, DC.pp17.

[3] Ansari, P.M. (2004). Water conservation in pulp and paper, distillery and sugar industry. In: Indo-EU workshop on promoting efficient water use in agro based industries, New Delhi, India

[4] Baruah, B.K., Baruah, D. and Das, M. (1996). Study on the effect of paper mill effluent on the water quality of receiving wetland. Poll. Res. 15(4), 389-393.

[5] Benjumea, D., Abdala, S., Hernandez-Luis, F., P'erezPaz, P. and Martin-Herrera, D. (2005). Diuretic activity of Artemisia thuscula, an endemic canary species. J Ethnopharmaco. 100, 205-209.

[6] Central Pulp and Paper Research Institute (CPPRI) (2005). Statistics of the Indian paper industry. In: directory of Indian paper industry, vol.11. Saharanpur, India.

[7] Choudhury, S.K., Jha, A.N. and Srivastava, D.K. (1987). Effect of paper mill effluent on seed germination and seedling growth of maize. Environ. Eco. 5(2), 285-287.

[8] CPCB, Delhi (2016). Final document on revised classification of industrial sectors under Red, Orange, Green and White categories.

[9] Duke, J.A. (2002). Handbook of Medicinal Herbs, second ed., CRC Press LLC, Boca Raton, Florida, USA, 222-23.

[10] Dutta, S.K. and Boissya, C.L. (1996). Effect of paper mill effluent on germination of rice seed (Oryza sativa L. Var Masuri) and growth behaviour of its seedling. J.Ind. Pollut. Cont. 2(2), 123-128.

[11]Evans, W.C., Trease and Evans (2002). Pharmacognocy. Fifteenth International edition, W.B. Saunders, Edinburgh, London, New York. 262.

[12] Garg, V.K. and Kaushik, P. (2006). Influence of shortterm irrigation of textile mill wastewater on the growth of chickpea cultivars. Chem. \& Ecol. 22(3), 193-200.

[13]Heidar, M. (1992). Coriandrum sativum In: application of plants in prevention and treatment of illnesses. Persian. 1: 257-252.

[14] Juwarkar, A.S., Bhalkar, D.V. and Subrahmanyam, P.V.R. (1987). Effect of pulp and paper mill waste water on soil properties. Indian J. of Env. Health. 29, 310-317.

[15] Kamlesh, and Kidwai, M.K. (2016). Effect of sugar mill effluent on response of Fenugreek (Trigonella foenum-graecum) varieties. IJEAB. 1(4), 844-852.

[16] Khanna, P.K; Mittar, D; Marwaha, S.S. and Kennedy, J.F. (1990). Characterization and bioblanching of paper mill effluents. Biopaper J; vol.10, pp.16.

[17] Kirk, T.K; Jeffries, T.W. and Leatham, G.F. (1983). Biotechnology: Applications and implications for the pulp and paper industry. Tappy J. pp. 6.

[18] Maghrani, M., Zeggwagh, N., Haloui, M., Eddouks, M. (2005). Acute diuretic effect of aqueous extract of Retamaraetam in normal rats. J. Ethnopharmacol. 99:31-35.

[19] Medhi, U.J., Talukdar, A.K. and Deka, S. (2008). Effect of pulp and paper mill effluent on seed germination and seedling growth of Mustard (Brassica campestris), Pea (Pisumsativam) and Rice (Oryzasatival) seeds. Poll Res. 27(3): 437-442.

[20] Pathak, N.L., Kasture, S.B., Bhatt, N.M. and Rathod, J.D. (2011). Phytopharmacological properties of Coriander sativum as a potential medicinal tree: an overview. J. of Applied Pharmaceu.Sci. 01(04), 20-25.

[21]Ragan, S.G. (1987). Pollution abatement in paper industry. IPPTA Convention Issue, 87, pp. 141. 
[22] Reddy, P.G. and Borse, R.D. (2001). "Effect of Pulp and Paper Mill Effluent on Seed Germination and Seedling Growth of Trigonella foenum-graceum L. (Methi), Journal of Industrial pollution control, Vol. 17, pp. 165-169.

[23] Singh, R.S; Marwaha, S.S; Gill, S.S. and Khanna, P.K. (1994). Pulp and paper industry waste water treatment - biotechnological approach. NIE J.4, pp. 16.

[24] Singh, Anoop Aggarwal, S.B., Rai, J.P.N. and Singh, Pratibha (2002). Assessment of the pulp and paper mill effluent on growth, yield and nutrient quality of wheat (Triticum aestivum L.). J.Environ. Biol., 23 (3): 283-288.

[25] Singh, S. (2004). An overview of Indian agro based paper mills. In: Tewari, P.K. (Ed.), Liquid asset, Proceedings of the Indo-EU work shop on promoting efficient water use in agro based industries. TERI press, New Delhi, pp. 31-33.

[26] Somashekar, R.K., Gowda, M.T., Shettigar, S.L.N. and Srinath, K.P. (1984). Effect of industrial effluent on crop plants. Indian J. Environ Health. 26(2), 136146.

[27] Subrahmanyam, P.V.R. and Hannmanulu, V. (1976): Economics of waste water treatment in small paper mills. IPFTA, 14, pp. 127.

[28] Tewari, P.K., Batra, V.S. and Balakrishnan, M. (2009). Efficient water use in industries: Cases from the Indian agro-based pulp and paper mills. Journal of Environ. Mgt. 90, 265-273.

[29] Thompson, G., Swain, J., Kay M. and Forster, C.F. (2001). The treatment of pulp and paper-mill effluent: A review. Biores. Technol. 77 (3): 275-286.

[30]Zargari, A. (1991). Coriandrum sativum L. In. Herbal Medicine, 1:586-90. 